\title{
Spectrophotometric Methods for the Quantitative Estimation of Paliperidone in Formulations
}

\author{
UMAMAHESWAR KORRAPATI and RAMBABU CHINTALA*
}

Department of Chemistry, Acharya Nagarjuna University, Nagarjuna Nagar, Guntur, Andhra Pradesh, India

rbchintala@gmail.com

Received 10 November 2013 / Accepted 29 December 2013

\begin{abstract}
Two simple, sensitive and economical spectrophotometric methods have been developed and validated for the determination of paliperidone in pharmaceutical dosage forms. The methods were based on the formation of colored complex of Paliperidone with different reagents. The absorbance of the formed colored complex is measured at the wavelength of maximum absorbance of the complex $665 \mathrm{~nm}$ and $555 \mathrm{~nm}$ respectively against the reagent blank treated similarly. These methods have different linearity ranges observed in the concentration ranges of 1-6 and 10-60 $\mu \mathrm{g} / \mathrm{mL}$ with correlation coefficient of 0.998 for both the methods. Statistical analysis indicates that the proposed methods are reproducible and selective for the estimation of Paliperidone in bulk drug and in its tablet dosage form.
\end{abstract}

Keywords: Paliperidone, Spectrophotometric Methods, Isatin, Chloranilic acid

\section{Introduction}

Paliperidone is a tricyclic dopamine antagonist of the atypical antipsychotic class of medications ${ }^{1-3}$ and is also known as 9-hydroxy risperidone (Figure 1). Paliperidone is used to treat mania and at lower doses as maintenance for bipolar disorder. It is also used for schizophrenia and schizoaffective disorder. Paliperidone (9-OH-risperidone) is a receptor monoaminergic antagonist that exhibits the characteristic dopamine type 2 (D2) and serotonin (5-hydroxytryptamine 5-HT) type 2A (5-HT2A) antagonism of antipsychotic $\operatorname{drugs}^{4,5}$. An extensive literature survey is carried out and very few spectrophotometric ${ }^{6}$ methods were found so far. Some LC-MS/MS methods ${ }^{7,8}$, HPTLC methods ${ }^{9,10}$, HPLC method $^{11,12}$ and a UPLC method ${ }^{13}$ for the determination of risperidone and the enantiomers of 9-hydroxyrisperidone in plasma, urine and pharmaceutical formulations respectively are available. We report two spectrophotometric methods for the determination of the drug. Molecular formula of paliperidone is $\mathrm{C}_{23} \mathrm{H}_{27} \mathrm{FN}_{4} \mathrm{O}_{3}$, Molecular weight is $426.484 \mathrm{~g} / \mathrm{mol}$.

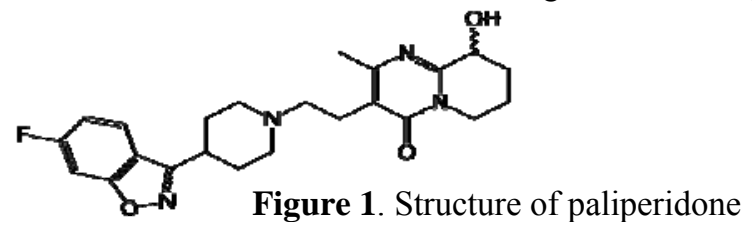




\section{Experimental}

All chemicals used were of analytical reagent grade and double distilled water was used to prepare all solutions. Double beam UV-Visible spectrophotometer is used for measuring the absorbance of the color formed during the analysis.

\section{Preparation of reagents}

\section{Isatin Method}

\section{Preparation of standard drug solution}

$10 \mathrm{mg}$ of the drug was taken in $10 \mathrm{~mL}$ of methanol. From this $1 \mathrm{~mL}$ was made up to $20 \mathrm{~mL}$ to get a concentration of $50 \mu \mathrm{g} / \mathrm{mL}$ and is used as a stock solution.

\section{Isatin solution}

$40 \mathrm{mg}$ of Isatin was dissolved in $100 \mathrm{~mL}$ of acetic acid.

\section{Procedure}

Aliquot of the drug solution was taken in a series of $10 \mathrm{~mL}$ volumetric flasks and to this $1 \mathrm{~mL}$ of Isatin was added and shaken well for $10 \mathrm{~min}$. To this, $1 \mathrm{~mL}$ of $\mathrm{H}_{2} \mathrm{SO}_{4}$ was added and shaken well for $5 \mathrm{~min}$. Final volume of the volumetric flask was made up to $10 \mathrm{~mL}$ with double distilled water. Then the absorbance of the colored solution was measured at $665 \mathrm{~nm}$ against a reagent blank.

\section{Chloranilic acid method}

\section{Preparation of standard drug solution}

$10 \mathrm{mg}$ of the drug was taken in $10 \mathrm{~mL}$ of methanol. From this, $2 \mathrm{~mL}$ was made up to $10 \mathrm{~mL}$ to get a concentration of $200 \mu \mathrm{g} / \mathrm{mL}$. This solution is used as a stock solution. Chloranilic acid solution (CA): Prepared by dissolving $100 \mathrm{mg}$ of chloranilic acid in $20 \mathrm{~mL}$ isopropanol initially followed by dilution with methanol to $100 \mathrm{~mL}$.

\section{Procedure}

Aliquots of standard drug solution were delivered into $10 \mathrm{~mL}$ graduated tubes. $2.0 \mathrm{~mL}$ of $\mathrm{CA}$ in methanol was added and kept aside for 5 minutes. Then the volumes of the contents were made up to the mark with methanol. The absorbance was measured against a reagent blank at $555 \mathrm{~nm}$.

\section{Results and Discussion}

\section{Method validation}

\section{Selection of analytical concentration ranges: (Linearity test)}

Linearity test was carried out by measuring the absorbance values of standard solutions. From the standard stock solution of paliperidone, appropriate aliquots were pipetted out in to a series of volumetric flasks and added the required solutions in the prescribed amounts for each individual method. After the color formation, absorbance of each concentration was measured at their corresponding wavelengths of maximum absorbance found (Figure 2 and 4) for the proposed methods. Results were shown in Table 1 and Table 2 for Isatin and chloralinic acid methods respectively and standard graphs of linearity for proposed methods were given in Figure 3 and 5 respectively. 


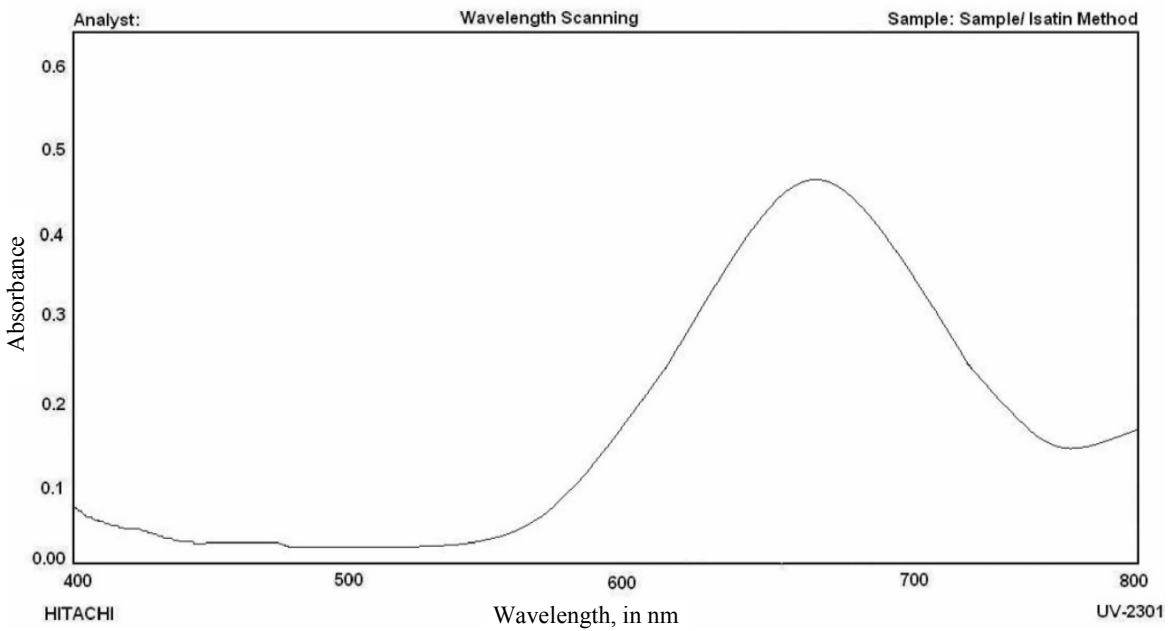

Figure 2. Wavelength Scan (Isatin Method)

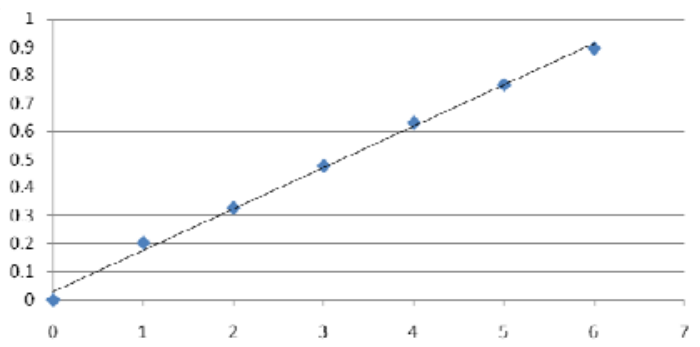

Figure 3. Calibration curves for the proposed methods

Table 1. Linearity - Isatin method

\begin{tabular}{ccc}
\hline S. No & Concentration in $\mu \mathrm{g} / \mathrm{mL}$ & Absorbance \\
\hline 1 & 1 & 0.204 \\
2 & 2 & 0.328 \\
3 & 3 & 0.478 \\
4 & 4 & 0.632 \\
5 & 5 & 0.767 \\
6 & 6 & 0.897 \\
\hline
\end{tabular}

Slope: 0.147 Intercept:0.03 Correlation Coefficient:0.998

Table 2. Linearity - CA method

\begin{tabular}{ccc}
\hline S. No & Concentration in $\mu \mathrm{g} / \mathrm{mL}$ & Absorbance \\
\hline 1 & 10 & 0.156 \\
2 & 20 & 0.301 \\
3 & 30 & 0.426 \\
4 & 40 & 0.556 \\
5 & 50 & 0.684 \\
6 & 60 & 0.824 \\
\hline
\end{tabular}

Slope: 0.013, Intercept:0.015, Correlation, Coefficient:0.998 


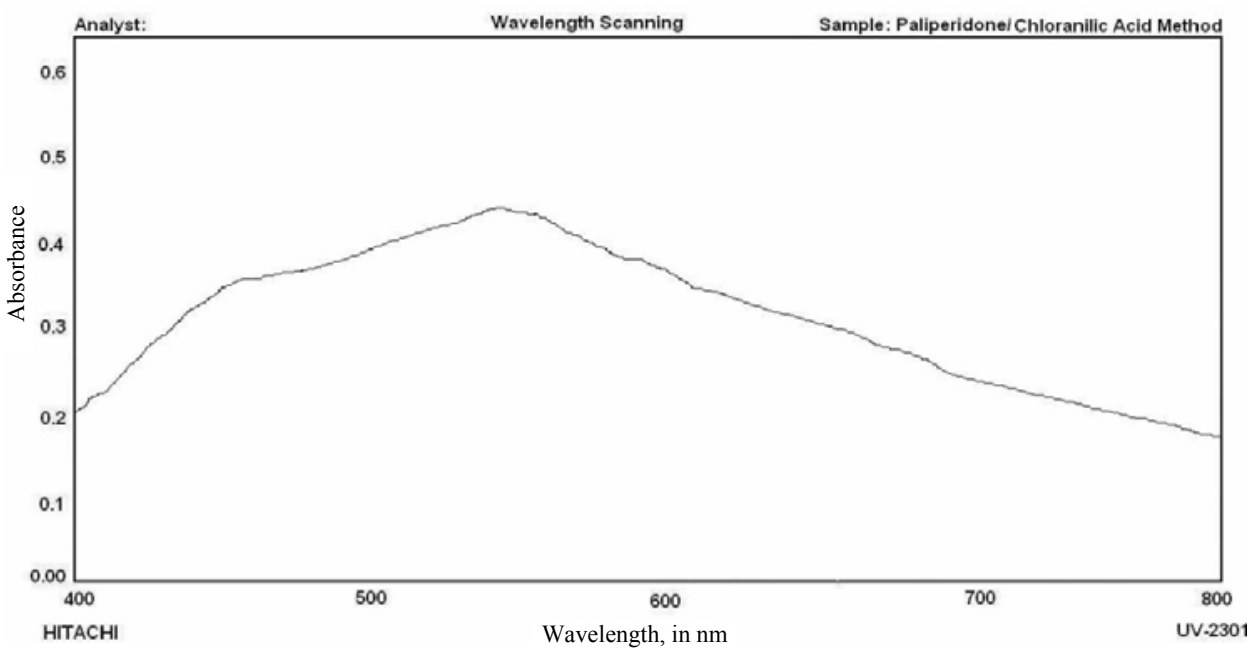

Figure 4. Wavelength scan (Chloranilic acid method)

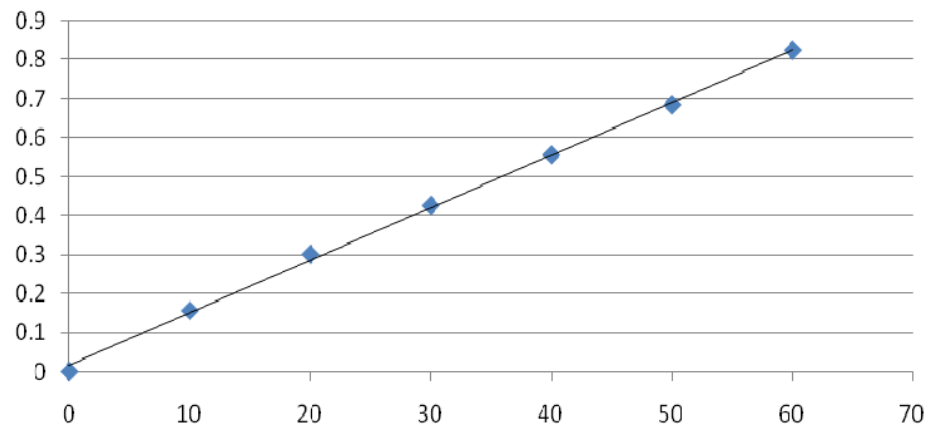

\section{Precision}

Figure 5. Calibration curves for the proposed methods

To evaluate the accuracy and precision of the methods, pure drug solution (Within the working limits) was analyzed and being repeated six times. The relative error (\%) and relative standard deviation (\%) were less than 2.0 and indicate the high accuracy and precision for the proposed methods (Table 3 and Table 4 ).

Table 3. Precision study (Isatin method)

\begin{tabular}{cccc}
\hline \multirow{2}{*}{ S.No } & $\begin{array}{c}\text { Concentration in } \\
\mu \mathrm{g} / \mathrm{mL}\end{array}$ & \multicolumn{2}{c}{ Absorbance } \\
\cline { 3 - 4 } & 3 & 0.472 & Intraday Precision \\
\hline 1 & 3 & 0.475 & Interday precision \\
2 & 3 & 0.476 & 0.468 \\
3 & 3 & 0.477 & 0.466 \\
4 & 3 & 0.474 & 0.467 \\
5 & 3 & 0.473 & 0.464 \\
6 & SD: & 0.001 & 0.461 \\
& Mean: & 0.47 & 0.002 \\
& RSD: & 0.35 & 0.46 \\
& & & 0.48 \\
\hline
\end{tabular}


Table 4. Precision study (Chloranilic acid method)

\begin{tabular}{cccc}
\hline \multirow{2}{*}{ S. No } & Concentration in $\mu \mathrm{g} / \mathrm{mL}$ & \multicolumn{2}{c}{ Absorbance } \\
\cline { 3 - 4 } & & Intraday Precision & Interday precision \\
\hline 1 & 30 & 0.428 & 0.416 \\
2 & 30 & 0.425 & 0.413 \\
3 & 30 & 0.427 & 0.415 \\
4 & 30 & 0.424 & 0.414 \\
5 & 30 & 0.423 & 0.412 \\
6 & 30 & 0.426 & 0.411 \\
& S.D & 0.001 & 0.0017 \\
& Mean: & 0.425 & 0.41 \\
& RSD: & 0.40 & 0.41 \\
\hline
\end{tabular}

\section{Recovery studies}

To ensure the accuracy and reproducibility of the results obtained, known amounts of pure drug was added to the previously analyzed formulation samples and these samples were reanalyzed by the proposed methods and also performed recovery experiments. The Percentage recoveries thus obtained were given in Table 5 and Table 6.

Table 5. Recovery results of the Isatin method

\begin{tabular}{cccccc}
\hline $\begin{array}{c}\% \text { of } \\
\text { Recovery }\end{array}$ & $\begin{array}{c}\text { Target Conc., } \\
\mu \mathrm{g} / \mathrm{mL}\end{array}$ & $\begin{array}{c}\text { Spiked conc., } \\
\mu \mathrm{g} / \mathrm{mL}\end{array}$ & $\begin{array}{c}\text { Final Conc., } \\
\mu \mathrm{g} / \mathrm{mL}\end{array}$ & $\begin{array}{c}\text { Conc., } \\
\text { Obtained }\end{array}$ & $\begin{array}{c}\% \\
\text { Recovery }\end{array}$ \\
\hline \multirow{2}{*}{$50 \%$} & 2 & 1 & 3 & 3.03 & 101.04 \\
& 2 & 1 & 3 & 3.01 & 100.62 \\
\multirow{2}{*}{$100 \%$} & 2 & 1 & 3 & 3.006 & 100.20 \\
& 2 & 2 & 4 & 4.04 & 101.10 \\
& 2 & 2 & 4 & 4.03 & 100.79 \\
$150 \%$ & 2 & 2 & 4 & 4.01 & 100.31 \\
& 2 & 3 & 5 & 4.98 & 99.73 \\
& 2 & 3 & 5 & 5.02 & 100.52 \\
& 2 & 3 & 5 & 5.05 & 101.17 \\
\hline
\end{tabular}

Table 6. Recovery results of the proposed Chloranilic acid method

\begin{tabular}{cccccc}
\hline $\begin{array}{c}\text { \% of } \\
\text { Recovery }\end{array}$ & $\begin{array}{c}\text { Target Conc., } \\
\mu \mathrm{g} / \mathrm{mL}\end{array}$ & $\begin{array}{c}\text { Spiked Conc., } \\
\mu \mathrm{g} / \mathrm{mL}\end{array}$ & $\begin{array}{c}\text { Final Conc., } \\
\mu \mathrm{g} / \mathrm{mL}\end{array}$ & $\begin{array}{c}\text { Conc., } \\
\text { Obtained }\end{array}$ & $\begin{array}{c}\% \\
\text { Recovery }\end{array}$ \\
\hline \multirow{2}{*}{$50 \%$} & 20 & 10 & 30 & 30.35 & 101.17 \\
& 20 & 10 & 30 & 30.14 & 100.46 \\
\multirow{3}{*}{$100 \%$} & 20 & 10 & 30 & 29.92 & 99.76 \\
& 20 & 20 & 40 & 40.35 & 100.8 \\
& 20 & 20 & 40 & 40.57 & 101.43 \\
$150 \%$ & 20 & 20 & 40 & 40.50 & 101.2 \\
& 20 & 30 & 50 & 50.51 & 101.02 \\
& 20 & 30 & 50 & 50.29 & 100.58 \\
\hline
\end{tabular}




\section{Stability studies}

The stability of the formed colour for the proposed methods was also studied and found to be 35 min for the Isatin method (99.16\% Assay) and for chloranilic acid method it is found to be $45 \min (98.35 \%$ Assay) and the details of the study were given in Table $7 \& 8$ respectively.

Table 7. Stability Study (Isatin method)

\begin{tabular}{cccc}
\hline S.No & Time, min & Absorbance found & \% Assay \\
\hline 1 & 0 & 0.478 & 100 \\
2 & 5 & 0.483 & 101.04 \\
3 & 10 & 0.481 & 100.62 \\
4 & 15 & 0.479 & 100.20 \\
5 & 20 & 0.484 & 101.25 \\
6 & 25 & 0.476 & 99.58 \\
7 & 30 & 0.475 & 99.37 \\
8 & 35 & 0.474 & 99.16 \\
9 & 40 & 0.468 & 97.90 \\
\hline
\end{tabular}

Table 8. Stability study

\begin{tabular}{cccc}
\hline S.No & Time, min & Absorbance found & \% Assay \\
\hline 1 & 0 & 0.426 & 100 \\
2 & 5 & 0.429 & 100.70 \\
3 & 10 & 0.428 & 100.46 \\
4 & 15 & 0.425 & 99.76 \\
5 & 20 & 0.427 & 100.23 \\
6 & 25 & 0.423 & 99.29 \\
7 & 30 & 0.421 & 98.82 \\
8 & 35 & 0.424 & 99.53 \\
9 & 40 & 0.42 & 98.59 \\
10 & 45 & 0.419 & 98.35 \\
11 & 50 & 0.416 & 97.65 \\
\hline
\end{tabular}

L.O.Q and L.O.D

The limits of detection and quantification of the two proposed methods were also analysed and reported in Table 9.

Table 9. LOD \& LOQ

\begin{tabular}{lcc}
\hline & Isatin method & Chloranilic acid method \\
\hline LOD & $0.075 \mu \mathrm{g} / \mathrm{mL}$ & $0.75 \mu \mathrm{g} / \mathrm{mL}$ \\
LOQ & $0.25 \mu \mathrm{g} / \mathrm{mL}$ & $2.5 \mu \mathrm{g} / \mathrm{mL}$ \\
\hline
\end{tabular}

\section{Application to analysis of commercial sample}

In order to check the validity of the proposed methods, paliperidone was determined in commercial formulation. From the results of the determination, it is clear that there is a close agreement between the results obtained by the proposed methods and the labelled claim. These results given in Table 10 indicate that there was no significant difference between the proposed methods and the reference methods in respect to accuracy and precision. 
Table 10. \% Assay

\begin{tabular}{cccccccc}
\hline S.No & Method & $\begin{array}{c}\text { Brand } \\
\text { name }\end{array}$ & $\begin{array}{c}\text { Available } \\
\text { form }\end{array}$ & $\begin{array}{c}\text { Label } \\
\text { claim }\end{array}$ & Concentration & $\begin{array}{c}\text { Amount } \\
\text { found, } \mu \mathrm{g} / \mathrm{mL}\end{array}$ & $\begin{array}{c}\% \\
\text { Assay }\end{array}$ \\
\hline 1. & Isatin & INVEGA & Tablet & $9.0 \mathrm{mg}$ & $3 \mu \mathrm{g} / \mathrm{ml}$ & 2.96 & 98.6 \\
2. & $\begin{array}{c}\text { Chloranilic } \\
\text { Acid }\end{array}$ & INVEGA & Tablet & $9.0 \mathrm{mg}$ & $30 \mu \mathrm{g} / \mathrm{ml}$ & 29.87 & 99.5 \\
\hline
\end{tabular}

\section{Acknowledgement}

One of the authors conveys his thanks to the management of RV Labs, Guntur for allowing him to carry out the analysis and providing gift sample of the drug.

\section{References}

1. Sandra B, Krishna T, Luc J, Bart R, Marc D M, Stefaan R, Nancy van O, Marielle E, and Adriaan C, J Clin Pharmacol., 2009, 49(11), 1318-1330; DOI:10.1177/0091270009339190

2. Owen R T, Drugs Today, 2007, 43(4), 249.

3. Green Ben, Bentham Science Publishers, Current Drug Therapy, 2009, 4(1), 7-11; DOI: $10.2174 / 157488509787081903$

4. Kane J, Canas F, Kramer M, Ford L, Gassmann-Mayer C, Lim P and Eerdekens M, Schizophr Res., 2007, 90(1-3), 147-161; DOI:10.1016/j.schres.2006.09.012

5. Christian D, Michael N and Zachariah D, Am J Health Sys Pharm., 2008, 65(5), 403413; DOI:10.2146/ajhp070261

6. Jane Mathew, Joshi Chintankumar K and Aghera Jonils, Int J Res Pharm Sci., 2011, 2(2), 158-161.

7. Marc De Meulder, Bart M M, Remmerie, Ronald de Vries, Luc L A, Sips, Sandra Boom, Edwin W J Hooijschuur, Nico C, van de Merbel and Philip M M B L, J Chromatogr B, 2008, 870(1), 8-16; DOI:10.1016/j.jchromb.2008.04.041

8. Manickam A and Stephen R M, J Mass Spectrom., 2000, 35(6), 718-724; DOI:10.1002/1096-9888(200006)35:6<718::AID-JMS999>3.0.CO;2-O

9. Shubhangi M Pawar and Sunil R Dhaneshwar, J Pharm Biomed Sci., 2012, 16(15), 1-5.

10. Rashmin B Patel, Mrunali R. Patel, Kashyap K Bhatt and Bharat G Patel, Anal Methods, 2010, 2, 525-531; DOI:10.1039/B9AY00276F

11. Sanjay A Jadhav Chromatogr Res Int. 2011, 10, 1.

12. Umamaheswar K, Ramu G and Rambabu C, Chem Sci Trans., 2013, 2(1), 41-46; DOI:10.7598/cst2013.268

13. Hima Bindu K, Nitin Haridas Dhekale, Suryanarayana M V and Anjaneyulu Y, $J$ Liquid Chromatogry Related Technol., 2012, 35(4), 533-546;

DOI:10.1080/10826076.2011.601503 